\title{
Microorganisms Associated with Hydrocarbon Contaminated Sites and Reservoirs for Microbial Enhanced Oil Recovery (MEOR)
}

Final CRADA Report

\author{
Energy Systems Division
}




\begin{abstract}
About Argonne National Laboratory
Argonne is a U.S. Department of Energy laboratory managed by UChicago Argonne, LLC under contract DE-AC02-06CH11357. The Laboratory's main facility is outside Chicago, at 9700 South Cass Avenue, Argonne, Illinois 60439. For information about Argonne and its pioneering science and technology programs, see www.anl.gov.
\end{abstract}

\title{
DOCUMENT AVAILABILITY
}

Online Access: U.S. Department of Energy (DOE) reports produced after 1991 and a growing number of pre-1991 documents are available free via DOE's SciTech Connect (http://www.osti.gov/scitech/)

Reports not in digital format may be purchased by the public from the National Technical Information Service (NTIS):

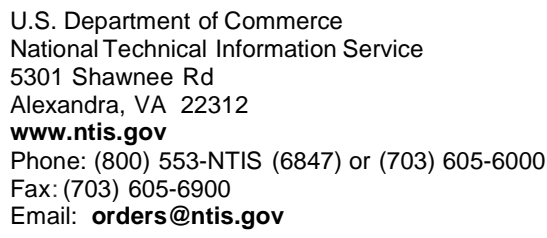

Reports not in digital format are available to DOE and DOE contractors from the Office of Scientific and Technical Information (OSTI):

\author{
U.S. Department of Energy \\ Office of Scientific and Technical Information \\ P.O. Box 62 \\ Oak Ridge, TN 37831-0062 \\ www.osti.gov \\ Phone: (865) 576-8401 \\ Fax: (865) 576-5728 \\ Email: reports@osti.gov
}

\section{Disclaimer}

This report was prepared as an account of work sponsored by an agency of the United States Government. Neither the United States Government nor any agency thereof, nor UChicago Argonne, LLC, nor any of their employees or officers, makes any warranty, express or implied, or assumes any legal liability or responsibility for the accuracy, completeness, or usefulness of any information, apparatus, product, or process disclosed, or represents that its use would not infringe privately owned rights. Reference herein to any specific commercial product, process, or service by trade name, trademark, manufacturer, or otherwise, does not necessarily constitute or imply its endorsement, recommendation, or favoring by the United States Government or any agency thereof. The views and opinions of document authors expressed herein do not necessarily state or reflect those of the United States Government or any agency thereof, Argonne National Laboratory, or UChicago Argonne, LLC. 


\section{Microorganisms Associated with Hydrocarbon Contaminated Sites and Reservoirs for Microbial Enhanced Oil Recovery (MEOR)}

Final CRADA Report

prepared by

M. Cristina Negri

Energy Systems Division, Argonne National Laboratory

October 21, 2013 


\section{FINAL CRADA REPORT}

Date: $10 / 21 / 2013$

CRADA Number: 1100501

CRADA Title: Microorganisms associated with hydrocarbon contaminated sites and reservoirs for Microbial Enhanced Oil Recovery (MEOR).

CRADA Start/End Date: Jan 30, 2012 to Jan 31, 2013

Argonne Dollars: $\$ 450,000$

Participant Dollars: $\$ 450,000$

Argonne PI: M. Cristina Negri

Industrial Partner:

DuPont Company

Experimental Station E402/4256

PO Box 80402

DOE Program Manager: Regina Carter, 202 586-8648, Regina.Carter@nnsa.doe.gov.

Summary of Major Accomplishments:

Russian partner Institutes tested a number of strains from their collection and/or selected at oilfield contamination/extraction sites to determine their ability to create aggregates that could plug oil well reservoirs to enhance oil recovery. Among these tested, five facultative anaerobic organisms that performed the best in the Russian Institutes' trials were shipped to Argonne and evaluated at Argonne for their ability to produce aggregates that plug pores in oil reservoirs formations. These organisms are non-pathogenic, non-toxic, thermotolerant halophiles or thermophilic organisms found in oil reservoirs and related environments. At Argonne, cells were grown aerobically and inoculated in anaerobic growth media each with a different carbon source and silica particles. After 4 days of anaerobic growth, the samples were evaluated for ability to plug oil reservoir formations. Results from the testing show that selected organisms provided encouraging results. Argonne proposed best candidate combinations for future testing using the premise that the test results should be at least $2 \mathrm{x}$ better than the control. Results were provided to the Industrial Partner who is interested in receiving the strains for further testing. The Industrial Partner will acquire directly from the Russian Institutes the license to use these strains. During the course of the project, the Industrial Partner coordinated with Argonne and the Russian partner Institutes, provided testing guidance, methods, and test materials and reviewed procedures and results.

Summary of Technology Transfer Benefits to Industry: The Industrial Partner is interested in testing the two best strains in their facility and are interacting with the Russian Institutes to obtain permission.

Other Information/Results: (Papers, Inventions, Software, etc.): Results from the project were considered proprietary and not disseminated through papers. 


\section{Argonne}

\section{Energy Systems Division}

Argonne National Laboratory

9700 South Cass Avenue, Bldg. \#362

Argonne, IL 60439

wWw.anl.gov 